\title{
High carrier prevalence with poor knowledge of thalassaemia among the university students from indigenous communities in Bangladesh
}

\author{
Md. Mahbub Hasan \\ University of Chittagong \\ Khaza Md. Kapil Uddin \\ University of Chittagong \\ Syed Mohammad Lokman \\ University of Chittagong \\ Adnan Mannan \\ University of Chittagong \\ Enayetur Raheem \\ Biomedical Research Foundation, Bangladesh

\section{Shahed Ahmad Chowdhury} \\ Chittagong Medical College \\ Mohammad Sorowar Hossain ( $\nabla$ sorowar.hossain@brfbd.org ) \\ Biomedical Research Foundation https://orcid.org/0000-0001-7143-2909
}

\section{Research}

Keywords: Bangladesh, Thalassaemia awareness, Indigenous students, Carrier screening, Carrier prevalence, Haemoglobinopathy

Posted Date: September 2nd, 2020

DOI: https://doi.org/10.21203/rs.3.rs-69965/v1

License: @ (i) This work is licensed under a Creative Commons Attribution 4.0 International License. Read Full License 


\section{Abstract \\ Background}

Thalassemia is an inherited life-threatening but preventable haemoglobin disorder. South Asian countries including Bangladesh are the hotspots of world's thalassemia belt. Indigenous communities are underprivileged and vulnerable to genetic disorders including thalassaemia. Understanding the perspectives of thalassemia of the future community leaders (indigenous university students) is critical for developing a tailor-made preventive strategy relevant to their communities. In this study, we aimed to assess the level of knowledge and attitudes towards thalassaemia among indigenous university students and determine their thalassemia carrier status.

\section{Methods}

A cross-sectional survey was conducted among 251 tribal university students using a published questionnaire between May and October 2018. Half of the students underwent thalassemia carrier screening by haemoglobin electrophoresis. Descriptive and inferential statistical procedures were used for data analysis.

\section{Results}

More than half (55\%) of the indigenous students had never heard the term 'thalassaemia'. Around half of the marriages in their communities were consanguineous. The mean knowledge score was very poor $(4.91 \pm 2.65)$ which was not associated study disciplines, and year of study. Nearly $39 \%$ of the students were found to be the carrier of E trait, while $1.8 \%$ of them had beta trait and 7\% E disease. Thalassaemia carrier status was not significantly correlated with sex, ethnicity, or home districts.

\section{Conclusions}

For the first time, this study has identified knowledge gaps and misperceptions about thalassaemia among university students from indigenous communities with a higher prevalence of thalassaemia. This study serves as a baseline for future interventions (premarital and prenatal screening) targeting future community leaders.

\section{Background}

Thalassemia is an inherited haemoglobin disorder, which has no cure, but it is preventable. Once found to be localized in certain parts of the world, thalassemia has become a global public health concern because of increasing international migration [1, 2]. An estimated 1-5\% of the world population are carriers of thalassaemia [2]. Nearly $90 \%$ of these births occur in developing countries [2]. In South Asia, particularly in India, Bangladesh, and Pakistan, thalassaemia has become a silent epidemic with an estimated 45-70 million thalassaemia carriers [3]. In Bangladesh, thalassaemia carriers' prevalence among the general population is estimated to be around 6-12\%, which translates into 10-19 million [4, 5]. An estimated 60,00070,000 patients have been suffering from severe forms of thalassaemia ( $\beta$-thalassaemia major and $\mathrm{HbE}$ beta) in the country [3]. Despite a higher prevalence of thalassemia carriers, people are mostly unfamiliar with this disease in Bangladesh [6].

The United Nations has declared that "indigenous peoples are recognized as being among the world's most vulnerable, disadvantaged and marginalized peoples" [7]. Out of approximately 390 million indigenous people globally, Bangladesh is the habitat of around 3 million people of these communities consisting of $1.8 \%$ of the total population (over 160 million). The indigenous or tribal people of Bangladesh mostly live in Chittagong hill tracts (CHT, 41\%). Among them, Chakma, Marma, and Tripura comprise the largest ethnic minority group consisting of $90 \%$ of the indigenous population living in $\mathrm{CHT}[8,9]$. Indigenous communities are underprivileged in terms of education and have less access to healthcare services, mainly because their habitats are located in the country's peripheral remote parts [10]. Nearly $82 \%$ of the children aged 5-19 years of age are 
enrolled in primary or secondary schools [11]. However, around two-thirds of them (65\%) fail to complete primary schooling, and another $19 \%$ of them are dropped after completion of primary education [11]. The main barriers to keep the tribal students in school are economic, social, remote access from the mainland and armed conflicts among different ethnic groups [11, 12].

Studies have shown that thalassemia carriers ( $\beta$-thalassaemia trait and $\mathrm{HbE}$ ) are highly prevalent (39-47\%) among indigenous populations [4]. However, the frequency of different thalassaemia types may vary from one region to another. About $70 \%$ of people from Asia, notably the northern regions of Thailand and Cambodia, carry HbE variant. In contrast, the frequency of alpha thalassaemia in the Mediterranean regions, the Middle East to the Indian subcontinent, and the East range 10-25\% [13]. Many recent reports have described the higher prevalence of alpha and $\mathrm{HbE}$ than $\beta$-thalassaemia among tribes/indigenous communities from China, Vietnam, Malaysia, and Thailand [14-19]. Given the vulnerable socio-economic conditions, inadequate access to healthcare, poor health awareness, and intra-tribal marriage practice, the higher prevalence of genetic disorders, including thalassemia is expected to accumulate defective genes within the population. Therefore, if this trend is allowed to continue, the tribal population's size will keep reducing gradually, which can further endanger this ethnic minority group.

In addition to the long-term consequences, there is another aspect of health equity for this minority group. Since indigenous people have less access to education, individuals who get an opportunity for higher studies at the university level, are expected to lead their communities. Therefore, understanding the perspective of thalassemia among indigenous university students could be a critical step towards developing a tailored made effective preventive strategy for their communities. In this study, we aimed to assess the level of knowledge and attitudes towards thalassaemia among indigenous university students and determine their thalassemia carrier status.

\section{Methods}

\section{Study setting}

This cross-sectional study was conducted between September 2018 and April 2019 in the students' residential settings (including university-run residential halls and private halls) at the University of Chittagong. Because of its geographic location where most indigenous communities live, and governmental policy promotes higher education, this University reserves seats for indigenous students in every department and institutes of eight faculties under a special quota system [20]. Thus, the University of Chittagong is the most appropriate setting for studying health issues like thalassemia of indigenous communities in Bangladesh.

\section{Sampling}

The estimated size of the targeted indigenous students studying at the University of Chittagong is 450 as per the admission office [21]. For an accuracy level of $95 \%$ with a confidence interval of $\pm 5.0 \%$, the calculated sample size was 207 [22]. For sampling, eight residential halls of tribal students, including three halls dedicated to female students, were randomly selected. Moreover, one classroom from the Department of Pali (the language of the Tipitaka) was also included because approximately two-thirds of the students in this department were from indigenous communities. Interviews in residential halls were conducted between 7:00 pm and 10:00 pm on weekdays to maximize the number of participants between May 2018 and October 2018. In contrast, for the academic classroom, the time was 11:00 am and 12:00 pm. Only students who were present physically at each residential hall were enrolled in this study. For all cases, a general announcement was made that a survey on a health-related issue (not mentioning thalassaemia) would take place. Students who agreed to sign the consent form were requested to gather in a large room of residential halls, and their responses were recorded in a printed questionnaire. A team of trained data enumerators, including the principal investigator, supervised the participants during data capture.

\section{Survey instrument}

In this study, a previously published questionnaire was used to assess college students' knowledge and attitudes in Bangladesh [6]. In brief, the questionnaire consisted of 22 questions with two major sections prepared in the Bengali language 
to avoid the language barrier. The demographic section questionnaire was revised to capture the indigenous characteristics of the participants.

Consent and demographic information of the participants were collected at the beginning of the survey. Participants were asked if they had heard of "thalassaemia". Those who answered "yes" were asked to proceed with the survey. The participants' knowledge about thalassaemia was subsequently assessed on 12 items. Of these, nine items were recorded using a 5-point Likert scale (strongly agreed, agreed, don't know, disagreed and strongly disagreed). These nine items were focused on general knowledge of thalassaemia, its carrier, and prevention. A correct response was given a score of one; an incorrect response was scored as -1 and 'don't know' was scored as zero, with higher scores indicating better knowledge. Participants' attitudes toward thalassaemia were assessed by eight items using a 5-point Likert scale. Data were managed and stored using REDCap electronic data capture tool hosted at Biomedical Research Foundation (BRF) for further processing (https://redcap.brfbd.org/).

\section{Carrier screening}

For thalassaemia carrier screening, blood samples were collected from interested participants. To maintain ethical guidelines, participants were called privately to know who was interested in carrier screening. Among them, 114 students (49 female and 65 male) participated in the second phase of the study, and written consent was retaken from each participant. All collected samples were then aliquoted into two Vacutainer containing $\mathrm{K}_{3}$ EDTA (Ethylenediaminetetraacetic acid). Haemoglobin electrophoresis of collected blood samples was carried out using Sebia full automated capillary electrophoresis system prescribed by the manufacturer (SEBIA - 27 rue Léonard de Vinci CP 8010 Lisses - 91008 Evry Cedex FRANCE). In this technique, different haemoglobin species are separated in silica capillaries according to their electrophoretic mobility and electroosmotic flow at a high voltage in an alkaline buffer $(\mathrm{pH} 9.4)$.

\section{Statistical analyses}

Descriptive and inferential statistical procedures were used to analyze the data. Categorical variables were presented using counts and percentages, and continuous variables were summarized using means and standard deviations. For testing the association between categorical variables, Pearson's chi-square test with continuity correction was used when necessary. The Likert scale measurements were summarized by computing the total scores. Means and standard deviations were calculated for the scores. For continuous variables, normality tests were performed first, and if needed, nonparametric Kruskal-Wallis oneway ANOVA tests were performed. A p-value smaller than 0.05 was considered significant. All data were analyzed using SPSS Statistics for Windows, Version 25.0 (SPSS Inc, Chicago, Illinois).

\section{Results}

\section{Respondent characteristics}

A total of 251 university students from indigenous communities participated in the study. Students came from 24 out of 25 upazilas (sub-districts) of Chittagong Hill Tracts (consisting of Bandarban, Rangamati, and Khagrachari) except Alikadam of Bandarban (Fig. 1). Most of them (91\%) were followers of the Buddhist religion. Two thirds $(67 \%)$ of the participants were from Arts and Humanities disciplines while the rest were from Social Science (13\%), Science (12\%), and Business Administration (8\%) (Table 1). 
Table 1

Demographic characteristics of participants and the proportion of the participants who heard the term/name of thalassaemia $(\mathrm{N}=251)$.

\begin{tabular}{|c|c|c|c|c|c|}
\hline \multirow[t]{3}{*}{ Variables } & \multirow{3}{*}{$\begin{array}{l}\text { All participants } \\
\mathrm{N}=251 \\
\mathrm{n}(\%)\end{array}$} & \multicolumn{2}{|c|}{$\begin{array}{l}\text { Have heard of thalassaemia } \\
\text { n (\%) }\end{array}$} & \multirow[t]{3}{*}{ Pearson's $\chi^{2}$} & \multirow[t]{3}{*}{$\mathrm{p}$} \\
\hline & & Yes & No & & \\
\hline & & $112(44.6 \%)$ & $139(55.4 \%)$ & & \\
\hline \multicolumn{6}{|l|}{ Gender } \\
\hline Male & $154(61.4 \%)$ & $62(40.3 \%)$ & $92(59.7 \%)$ & 3.068 & 0.080 \\
\hline Female & $97(38.6 \%)$ & $50(51.5 \%)$ & $47(48.5 \%)$ & & \\
\hline \multicolumn{6}{|l|}{ Permanent address } \\
\hline Bandarban & $32(12.7 \%)$ & $20(62.5 \%)$ & $12(37.5 \%)$ & 6.818 & 0.078 \\
\hline Cox's Bazar & $4(1.6 \%)$ & $3(75 \%)$ & $1(25 \%)$ & & \\
\hline Khagrachari & $94(37.5 \%)$ & $37(39.4 \%)$ & $57(60.6 \%)$ & & \\
\hline Rangamati & $121(48.2 \%)$ & $52(43 \%)$ & $69(57 \%)$ & & \\
\hline \multicolumn{6}{|l|}{ Discipline studying } \\
\hline Arts and Humanities & $167(66.5 \%)$ & $71(42.5 \%)$ & $96(57.5 \%)$ & 16.33 & 0.001 \\
\hline Business Administration & $21(8.4 \%)$ & $10(47.6 \%)$ & $11(52.4 \%)$ & & \\
\hline Science & $31(12.4 \%)$ & $23(74.2 \%)$ & $8(25.8 \%)$ & & \\
\hline Social Sciences & $32(12.7 \%)$ & $8(25 \%)$ & $24(75 \%)$ & & \\
\hline \multicolumn{6}{|l|}{ Year of study } \\
\hline 1st Year & $26(10.4 \%)$ & $7(26.9 \%)$ & $19(73.1 \%)$ & 5.258 & 0.262 \\
\hline 2nd Year & $81(32.3 \%)$ & $38(46.9 \%)$ & $43(53.1 \%)$ & & \\
\hline 3rd Year & $48(19.1 \%)$ & $19(39.6 \%)$ & $29(60.4 \%)$ & & \\
\hline 4th Year & $56(22.3 \%)$ & $27(48.2 \%)$ & $29(51.8 \%)$ & & \\
\hline MS & $40(15.9 \%)$ & $21(52.5 \%)$ & $19(47.5 \%)$ & & \\
\hline \multicolumn{6}{|l|}{ Ethnicity } \\
\hline Chakma & $164(65.3 \%)$ & $71(43.3 \%)$ & $93(56.7 \%)$ & 15.067 & 0.005 \\
\hline Marma & $46(18.3 \%)$ & $24(52.2 \%)$ & $22(47.8 \%)$ & & \\
\hline Tanchangya & $16(6.4 \%)$ & $11(68.8 \%)$ & $5(31.3 \%)$ & & \\
\hline Tripura & 19 (7.6\%) & $2(1.8 \%)$ & $17(12.2 \%)$ & & \\
\hline Others & $6(2.4 \%)$ & $4(66.7 \%)$ & $2(33.3 \%)$ & & \\
\hline \multicolumn{6}{|l|}{ Religion } \\
\hline Buddhist & $228(90.8 \%)$ & $109(47.8 \%)$ & $119(52.2 \%)$ & 10.218 & 0.001 \\
\hline Others & $23(9.2 \%)$ & $3(13 \%)$ & $20(87 \%)$ & & \\
\hline
\end{tabular}


Among 251 participants, 123 (49\%) reported that their parents were closely related to each other, second cousins, or closer (Table 2). The rate of consanguineous marriage was significantly higher $(p<0.001)$ among tribal residing in Rangamati $(63 \%)$, whereas the lowest among tribal from Bandarban $(16 \%)$. This practice was correlated with ethnicity $(p<0.001)$ and religious beliefs $(p<0.001)$. Indigenous students from Chakma were more likely $(70 \%)$ to marry close relatives (second cousins or closer).

Table 2

Correlation of consanguineous marriage among families of tribal students of Chittagong University $(\mathrm{N}=251)$

\begin{tabular}{|c|c|c|c|c|}
\hline \multirow[t]{3}{*}{ Variables } & \multicolumn{2}{|c|}{$\begin{array}{l}\text { Parents are closely related } \\
\text { n (\%) }\end{array}$} & \multirow[t]{3}{*}{ Pearson's $\chi^{2}$} & \multirow[t]{3}{*}{ p } \\
\hline & Yes & No & & \\
\hline & $123(49 \%)$ & $128(51 \%)$ & & \\
\hline \multicolumn{5}{|c|}{ Permanent address } \\
\hline Bandarban & $5(15.6 \%)$ & 27 (84.4\%) & 25.51 & $<0.0001$ \\
\hline Cox's Bazar & $1(25 \%)$ & $3(75 \%)$ & & \\
\hline Khagrachari & $41(43.6 \%)$ & $53(56.4 \%)$ & & \\
\hline Rangamati & $76(62.8 \%)$ & 45 (37.2\%) & & \\
\hline \multicolumn{5}{|l|}{ Ethnicity } \\
\hline Chakma & $115(70.1 \%)$ & 49 (29.9\%) & 85.803 & $<0.0001$ \\
\hline Marma & $4(8.7 \%)$ & $42(91.3 \%)$ & & \\
\hline Tanchangya & $3(18.8 \%)$ & $13(81.3 \%)$ & & \\
\hline Tripura & 0 & $19(100 \%)$ & & \\
\hline Others & $1(16.7 \%)$ & $5(83.3 \%)$ & & \\
\hline \multicolumn{5}{|l|}{ Religion } \\
\hline Buddhist & $122(53.5 \%)$ & $106(46.5 \%)$ & 20.205 & $<0.0001$ \\
\hline Others & $1(4.3 \%)$ & $22(95.7 \%)$ & & \\
\hline
\end{tabular}

More than half (55\%) of the participants were unfamiliar with the word "thalassaemia". The proportion of students who had heard about thalassaemia was associated with study disciplines $(p=0.001)$, different indigenous ethnicity $(p=0.005)$, and religious belief $(p=0.001)$. While the majority $(\sim 74 \%)$ of the students from the Science disciplines had heard of thalassaemia, $\sim 48 \%$ from Business Administration, 43\% Arts and Humanities and only 25\% students from Social Science faculty had heard of thalassaemia (Table 1).

\section{Knowledge on thalassaemia}

Knowledge and attitude were assessed among 112 (44.6\%) respondents who declared to have heard about "Thalassemia." The frequently mentioned source of information about thalassemia was the internet (28\%), Friends (24\%), and Facebook (22\%) (Additional file 1). Table 3 reports the distribution of responses of 12 knowledge related questions among indigenous students who had heard about thalassaemia. Overall, knowledge of prevention and treatment of thalassaemia among respondents was poor. Only $20 \%$ answered correctly that thalassaemia is a preventable disease if the marriage between carriers is prevented, and more than half of the participants replied that they had no idea about the prevention of the disease. The mean knowledge score was very poor $(4.91 \pm 2.65)$. The knowledge level was significantly $(p=0.003)$ higher in females than males. However, knowledge scores were not associated with the disciplines, duration of education, and religious beliefs (Table 4). 
Table 3

Distribution of responses (correct/incorrect/doesn't know) of 12 knowledge related questions among students who have heard about thalassaemia $(n=112)$.

\begin{tabular}{|c|c|c|c|}
\hline Questions & $\begin{array}{l}\text { Correct n } \\
(\%)\end{array}$ & $\begin{array}{l}\text { Incorrect n } \\
(\%)\end{array}$ & $\begin{array}{l}\text { Don't know } \\
\text { n (\%) }\end{array}$ \\
\hline 1. Thalassaemia is a contagious disease (NO) & $\begin{array}{l}62 \\
(55.4 \%)\end{array}$ & $11(9.8 \%)$ & $39(34.8 \%)$ \\
\hline 2. Thalassaemia is a genetic disease (Yes) & $\begin{array}{l}71 \\
(63.4 \%)\end{array}$ & $9(8 \%)$ & $32(28.6 \%)$ \\
\hline $\begin{array}{l}\text { 3. Thalassaemia could be transmitted through blood transfusion from a person } \\
\text { with thalassaemia (No) }\end{array}$ & $19(17 \%)$ & $47(42 \%)$ & $46(41.1 \%)$ \\
\hline $\begin{array}{l}\text { 4. Marriage between two carriers can lead to a child with thalassaemia major } \\
\text { (Yes) }\end{array}$ & $\begin{array}{l}77 \\
(68.8 \%)\end{array}$ & $3(2.7 \%)$ & $32(28.6 \%)$ \\
\hline $\begin{array}{l}\text { 5. If one parent is a carrier, the couple has a chance of having a child with } \\
\text { thalassaemia disease (No) }\end{array}$ & $\begin{array}{l}24 \\
(21.4 \%)\end{array}$ & $56(50 \%)$ & $32(28.6 \%)$ \\
\hline $\begin{array}{l}\text { 6. Marriage between close relatives can increase the chance of thalassaemia } \\
\text { (Yes) }\end{array}$ & $\begin{array}{l}40 \\
(35.7 \%)\end{array}$ & $\begin{array}{l}22 \\
(19.6 \%)\end{array}$ & $50(44.6 \%)$ \\
\hline 7. Thalassaemia carriers are as healthy as normal people (Yes) & $\begin{array}{l}39 \\
(34.8 \%)\end{array}$ & $28(25 \%)$ & $45(40.2 \%)$ \\
\hline 8. Thalassaemia is a preventable disease (Yes) & $\begin{array}{l}22 \\
(19.6 \%)\end{array}$ & $\begin{array}{l}30 \\
(26.8 \%)\end{array}$ & $60(53.6 \%)$ \\
\hline 9. Thalassaemia is a completely curable disease (No) & $\begin{array}{l}21 \\
(18.8 \%)\end{array}$ & $\begin{array}{l}32 \\
(28.6 \%)\end{array}$ & $59(52.6 \%)$ \\
\hline $\begin{array}{l}\text { 10. Which part of the human body or organ is affected by Thalassaemia? (Blood } \\
\text { or circulatory system) }\end{array}$ & $\begin{array}{l}25 \\
(22.3 \%)\end{array}$ & $3(2.7 \%)$ & $84(75 \%)$ \\
\hline 11. Anyone could be a thalassaemia carrier including you. (Yes) & $\begin{array}{l}67 \\
(59.8 \%)\end{array}$ & $\begin{array}{l}45 \\
(40.2 \%)\end{array}$ & $0(0 \%)$ \\
\hline 12. Thalassaemia can be identified by blood test (Yes) & $\begin{array}{l}83 \\
(74.1 \%)\end{array}$ & $\begin{array}{l}29 \\
(25.9 \%)\end{array}$ & $0(0 \%)$ \\
\hline
\end{tabular}


Association between demographic variables and total thalassaemia knowledge scores.

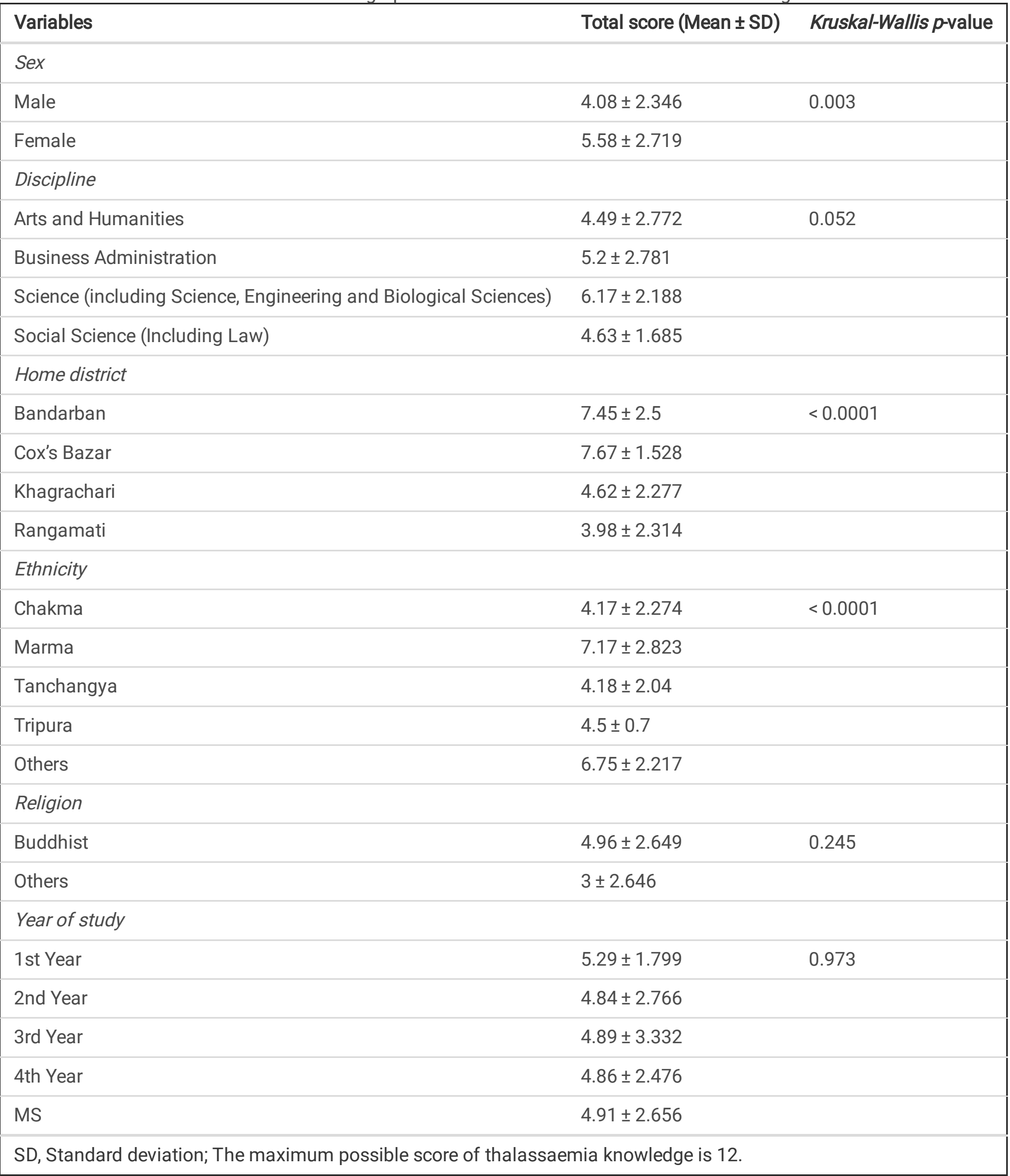

\section{Attitudes towards thalassaemia}

The attitudes of the indigenous students towards thalassaemia are presented in Additional file 2. The majority (91.1\%) of the tribal students would prefer premarital screening to eradicate thalassaemia from society. More than two-thirds (69.6\%) of them had positive attitudes to donate blood to thalassemic patients. Three-fourths (75.9\%) want to be a friend of thalassemic 
patients, and most of them (95.5\%) showed positive attitudes to raise awareness among their community to prevent the disease.

\section{Prevalence of thalassaemia carrier among indigenous participants}

A total of 114 participants underwent thalassaemia carrier screening but the carrier status of four individuals could not be determined (Table 5). We found that $48.2 \%$ of the participants were non-carriers, while $40.4 \%$ were carriers $(38.6 \% \mathrm{E}$ trait and $1.8 \%$ beta trait). E-disease (E-E genotype) was found among $7 \%$ individuals while one E-beta case (0.9\%) was identified.

Thalassemia carriers' carrier status was not significantly correlated with sex, ethnicity, or home district (Table 5).

Table 5

Prevalence of thalassaemia among tribal students from different ethnic groups studying at the University of Chittagong ( $\mathrm{N}=$ 114).

\begin{tabular}{|c|c|c|c|c|c|c|c|c|c|}
\hline \multirow[t]{2}{*}{ Variables } & \multicolumn{6}{|c|}{ Diagnosis, \% (n) } & \multirow[t]{2}{*}{ Total } & \multirow{2}{*}{$\begin{array}{l}\text { Pearson's } \\
x^{2}\end{array}$} & \multirow[t]{2}{*}{$\mathrm{p}$} \\
\hline & $\begin{array}{l}\text { Beta- } \\
\text { Carrier }\end{array}$ & $\begin{array}{l}\text { E-Beta } \\
\text { Thalassemia }\end{array}$ & $\begin{array}{l}\text { E-E } \\
\text { homozygous }\end{array}$ & $\begin{array}{l}\text { E- } \\
\text { Trait }\end{array}$ & $\begin{array}{l}\text { Non- } \\
\text { carrier }\end{array}$ & Undetermined & & & \\
\hline \multicolumn{10}{|l|}{ Ethnicity } \\
\hline Chakma & $\begin{array}{l}1.8 \% \\
(2)\end{array}$ & $0.9 \%(1)$ & $4.4 \%(5)$ & $\begin{array}{l}23.7 \% \\
(27)\end{array}$ & $\begin{array}{l}34.2 \% \\
(39)\end{array}$ & 0 & $\begin{array}{l}64.9 \% \\
(74)\end{array}$ & 25.589 & 0.18 \\
\hline Marma & $0 \%(0)$ & $0 \%(0)$ & $0 \%(0)$ & $\begin{array}{l}6.1 \% \\
(7)\end{array}$ & $\begin{array}{l}8.8 \% \\
(10)\end{array}$ & $2.6 \%(3)$ & $\begin{array}{l}17.5 \% \\
(20)\end{array}$ & & \\
\hline Tripura & $0 \%(0)$ & $0 \%(0)$ & $0 \%(0)$ & $\begin{array}{l}3.5 \% \\
(4)\end{array}$ & $\begin{array}{l}3.5 \% \\
(4)\end{array}$ & $0.9 \%(1)$ & $\begin{array}{l}7.9 \% \\
(9)\end{array}$ & & \\
\hline Tanchangya & $0 \%(0)$ & $0 \%(0)$ & $1.8 \%(2)$ & $\begin{array}{l}3.5 \% \\
(4)\end{array}$ & $\begin{array}{l}0.9 \% \\
(1)\end{array}$ & $0 \%(0)$ & $\begin{array}{l}6.1 \% \\
(7)\end{array}$ & & \\
\hline Others & $0 \%(0)$ & $0 \%(0)$ & $0.9 \%(1)$ & $\begin{array}{l}1.8 \% \\
(2)\end{array}$ & $\begin{array}{l}0.9 \% \\
(1)\end{array}$ & $0 \%(0)$ & $\begin{array}{l}3.5 \% \\
(4)\end{array}$ & & \\
\hline \multicolumn{10}{|l|}{ District } \\
\hline Bandarban & $0 \%(0)$ & $0 \%(0)$ & $1.8 \%(2)$ & $\begin{array}{l}7 \% \\
(8)\end{array}$ & $\begin{array}{l}4.4 \% \\
(5)\end{array}$ & $0.9 \%(1)$ & $\begin{array}{l}14 \% \\
(16)\end{array}$ & 6.502 & 0.771 \\
\hline Khagrachari & $\begin{array}{l}0.9 \% \\
(1)\end{array}$ & $0 \%(0)$ & $0.9 \%(1)$ & $\begin{array}{l}13.2 \% \\
(15)\end{array}$ & $\begin{array}{l}21.1 \% \\
(24)\end{array}$ & $0.9 \%(1)$ & $\begin{array}{l}36.8 \% \\
(42)\end{array}$ & & \\
\hline Rangamati & $\begin{array}{l}0.9 \% \\
(1)\end{array}$ & $0.9 \%(1)$ & $4.4 \%(5)$ & $\begin{array}{l}18.4 \% \\
(21)\end{array}$ & $\begin{array}{l}22.8 \% \\
(26)\end{array}$ & $1.8 \%(2)$ & $\begin{array}{l}49.1 \% \\
(56)\end{array}$ & & \\
\hline \multicolumn{10}{|l|}{ Sex } \\
\hline Female & $\begin{array}{l}1.8 \% \\
(2)\end{array}$ & $0 \%(0)$ & $4.4 \%(5)$ & $\begin{array}{l}13.2 \% \\
(15)\end{array}$ & $\begin{array}{l}23.7 \% \\
(27)\end{array}$ & $0 \%(0)$ & $\begin{array}{l}43 \% \\
(49)\end{array}$ & 9.923 & 0.077 \\
\hline Male & $0 \%(0)$ & $0.9 \%(1)$ & $2.6 \%(3)$ & $\begin{array}{l}25.4 \% \\
(29)\end{array}$ & $\begin{array}{l}24.6 \% \\
(28)\end{array}$ & $3.5 \%(4)$ & $\begin{array}{l}57 \% \\
(65)\end{array}$ & & \\
\hline Total & $\begin{array}{l}1.8 \% \\
(2)\end{array}$ & $0.9 \%(1)$ & $7 \%(8)$ & $\begin{array}{l}38.6 \% \\
(44)\end{array}$ & $\begin{array}{l}48.2 \% \\
(55)\end{array}$ & $3.5 \%(4)$ & $\begin{array}{l}100 \% \\
(114)\end{array}$ & & \\
\hline
\end{tabular}

\section{Discussion}

This study's primary objective was to understand the knowledge and perceptions of thalassaemia among university students of the indigenous communities in Bangladesh. Against the backdrop of a higher prevalence of thalassemia carriers, our study has identified a significant knowledge gap and misconceptions about thalassaemia among the indigenous communities' highly educated segment. 
In this study, the finding of a higher prevalence of $\mathrm{HbE}(38.6 \%)$ trait within indigenous communities is consistent with previous studies. It appears that the Tanchangya tribe was more prone to have a higher proportion of $\mathrm{HbE}$ trait (57.1\%) and the homozygous of E trait, named $\mathrm{HbE}$ disease (28.6\%). Long-term health consequences of $\mathrm{HbE}$ disease are not well understood, and individuals with $\mathrm{HbE}$ disease are healthy. However, in our prior study conducted in a specialized thalassemia hospital, we found a few cases (6 out of 11) of patients with E disease requiring regular or occasional blood transfusion [4]. On the other hand, the beta trait prevalence was relatively less common (1.8\%) in the present study. However, previous studies documented a relatively higher beta trait prevalence ranging from 3-4.8\% [23]. It is important to mention that the severe version (transfusiondependent) of thalassemia resulting from coinheritance beta and $\mathrm{HbE}$ trait is highly prevalent (complex heterozygous, E-beta vs homozygous thalassemia major: $77 \%$ vs. $15 \%$ ) in Bangladesh and south-western regions of India (West Bengal). Our previous study has shown that more than $50 \%$ of the patients with E-beta thalassemia require regular blood transfusion for survival [4]. It is alarming that without effective interventions, the higher prevalence of thalassemia carriers among indigenous communities in this part of the world may jeopardize their long-term perspective.

Consanguineous marriage practice might be responsible for the higher prevalence of thalassemia carriers within the indigenous communities. Nearly $50 \%$ of marriages were consanguineous in the present study, while consanguineous marriage practice is less common in Teknaf, Chittagong region (17.6\%) among non-indigenous populations [24]. Notably, around $70 \%$ of marriage practice was contagious in the Chakma tribe living in Rangamati. One reason behind the much higher prevalence of consanguineous marriage practice in Rangamati is that it is a district of lakes and hills where free movements are not easy. In this study, $50 \%$ of the thalassemia carriers were from Rangamati, indicating the accumulation of defective genes might be linked to consanguineous marriage.

We found most tribal university students (55\%) have not heard of the word- 'thalassemia.' Best of our knowledge, there is no local dialect synonymous with thalassemia in the indigenous communities. In Bangladesh, nearly 100 million people are internet subscribers [25]. About 39 million of them use social media (Facebook). Young aged students (18-24 years) are the largest user of Facebook [26]. Despite easy access to the internet on university campuses, the proportion of the indigenous students who heard about thalassemia is unexpectedly low (45\%).

On the other hand, the overall knowledge scores of the participants who heard about thalassemia were poor irrespective of study disciplines and years of study at the university. For instance, only one-third ( 35\%) of the respondents knew that thalassemia carriers are as healthy as ordinary people. Only one out of five (20\%) tribal students answered correctly that thalassaemia is a preventable disease. In our previous study among college students in the mainland, we found that students with a science background were more familiar with thalassemia since their school curriculum (standard IX and X) dedicated few sentences on thalassemia. Despite having thalassemia related information in the curriculum, the overall knowledge scores were also poor among college students [6]. In general, about $20 \%$ of high school students enroll in the science discipline and most of them from urban settings. In this study, we found that most indigenous students had arts and humanities backgrounds (66\%), while only $12 \%$ had science backgrounds. As the first step for an effective thalassemia prevention strategy, the inclusion of thalassemia-related information in all disciplines' school curriculum could be highly effective [6]. However, as mentioned earlier, nearly $85 \%$ of the tribal students are dropped out before and after the primary level. Thus, unlike students in the general population, the targeting of school level students might not be effective for indigenous communities.

Given the fact that indigenous communities are marginalized and live in the remote part of the country where there is less access to education, information and healthcare facilities Without sensing the communities regarding genetic disorders like thalassemia, any preventive attempt is expected to backfire. In this context, educating future community leaders (university students) about the consequence of thalassemia could be a highly effective intervention approach to prevent thalassemia in these communities.

Randomly selected sampling with reasonably large sample size is the strength of this study. However, our study was 'cohortbased' targeting mostly indigenous students of a particular region of Bangladesh (around half the tribal population live here); our findings may not be generalizable to the entire indigenous population. 


\section{Conclusions}

Best of our knowledge, this is the first study of its kind to identify knowledge gaps and misperceptions about thalassemia among disadvantaged indigenous communities in Bangladesh and perhaps elsewhere in the world. Despite a higher prevalence of thalassemia carriers among indigenous university students, our study has revealed that nearly half the participants had not heard about thalassemia, and those who are familiar had a poor level of knowledge. Without implementing an effective thalassemia prevention strategy emphasizing awareness, carrier screening, prenatal diagnosis, the existence of the indigenous communities in South Asian might be in danger because of a higher prevalence of thalassemia carriers. Findings from this study would contribute to formulating effective intervention programs by engaging university graduates- the future community leaders of the most disadvantaged communities in the world.

\section{Declarations}

\section{Acknowledgments}

The authors acknowledge the contribution of Mr. Kallyan Chakma and Aung Chaing-U Pulu from the Department of Genetic Engineering and Biotechnology, University of Chittagong, for their support during the data collection period. We would also like to thank Dr. Mahbubul H Siddiqee, Biomedical Research Foundation, Bangladesh, to review our manuscript.

\section{Ethics approval and consent to participate}

This study's ethical approval was obtained from the Chittagong Medical College and Hospital (Memo: CMC/PG/2018/50, dated 17-04-2018). The data collection questionnaire did not contain any personal information of participants. Written consent was obtained from each participant.

\section{Consent for publication}

Not applicable as no recognizable personal data is not disclosed.

Availability of data and materials

Data generated in this study are not publicly available. Only aggregate summary has been provided in the manuscript.

\section{Funding}

The study was funded partially to carry out the survey and screening by the Research \& Publication Cell of the University of Chittagong (Ref. Research/Cell/CU/6429/2018) and Bangladesh Thalassaemia Hospital, Dhaka, Bangladesh.

\section{Author Contribution}

$\mathrm{MMH}, \mathrm{MSH}$ and ER conceived and designed the study. MMH, KMKU, and SML conducted the research work. MMH and ER analyzed all the data. MMH and MSH prepared the first manuscript draft. MSH, MMH, ER, AM and SAC critically reviewed and revised the draft. All authors read and approved the final manuscript.

\section{Competing interests}

The author declares no competing interests.

\section{References}

1. De Sanctis V, Kattamis C, Canatan D, Soliman AT, Elsedfy H, Karimi M, et al. beta-Thalassemia Distribution in the Old World: an Ancient Disease Seen from a Historical Standpoint. Mediterr J Hematol Infect Dis. 2017;9(1):e2017018.

2. Taher AT, Weatherall DJ, Cappellini MD. Thalassaemia. Lancet. 2018;391(10116):155-67. 
3. Dhar-Chowdhury P, Paul KK, Haque CE, Hossain S, Lindsay LR, Dibernardo A, et al. Dengue seroprevalence, seroconversion and risk factors in Dhaka, Bangladesh. PLoS Negl Trop Dis. 2017;11(3):e0005475.

4. Hossain MS, Raheem E, Sultana TA, Ferdous S, Nahar N, Islam S, et al. Thalassemias in South Asia: clinical lessons learnt from Bangladesh. Orphanet Journal of Rare Diseases. 2017;12(1):93.

5. Noor FA, Sultana N, Bhuyan GS, Islam MT, Hossain M, Sarker SK, et al. Nationwide carrier detection and molecular characterization of beta-thalassemia and hemoglobin E variants in Bangladeshi population. Orphanet J Rare Dis. 2020;15(1):15.

6. Hossain MS, Hasan MM, Raheem E, Islam MS, Al Mosabbir A, Petrou M, et al. Lack of knowledge and misperceptions about thalassaemia among college students in Bangladesh: a cross-sectional baseline study. Orphanet J Rare Dis. 2020;15(1):54.

7. UHCHR. The United Nations Declaration on the Rights of Indigenous Peoples A Manual for National Human Rights Institutions. In. CH-1211 Geneva 10, Switzerland https://www.ohchr.org/documents/issues/ipeoples/undripmanualfornhris.pdf: Office of the United Nations High Commissioner for Human Rights; 2013.

8. Indigenous. peoples in Bangladesh https://www.iwgia.org/en/bangladesh.

9. Cummins P, Chakma AK, Rahman SH. Strengthening Basic Education in the Chittagong Hill Tracts Phase II. In. Rangagmati. Bangladesh: United Nations Development Programme; 2012.

10. BBS: District Statistics. 2011. In.: Statistics and Informatics Division (SID), Bangladesh Bureau of Statistics. Available at http://www.bbs.gov.bd/site/page/2888a55d-d686-4736-bad0-54b70462afda/; 2013.

11. MoHFW. Tribal/Ethnic Health Population and Nutrition Plan. In. Edited by Ministry of Health and Family Welfare GoB. Dhaka, Bangladesh. Available at http://documents.worldbank.org/curated/pt/874871468198578021/pdf/E26060V30P118710MarOdisclosable0ver.pdf: The World Bank.; 2016.

12. Hossain DM. Socio-Economic Situation of the Indigenous People in the Chittagong Hill Tracts (CHT) of Bangladesh. Middle East Journal of Business. 2013;8(2):22-30.

13. Williams TN, Weatherall DJ. World distribution, population genetics, and health burden of the hemoglobinopathies. Cold Spring Harb Perspect Med. 2012;2(9):a011692.

14. Zhao P, Weng R, Wu H. Molecular Spectrum of alpha- and beta-Thalassemia Mutations in a Large Ethnic Hakka Population in Southern China. Hemoglobin. 2018;42(2):117-21.

15. Anh TM, Sanchaisuriya K, Kieu GN, Tien DN, Thu HBT, Sanchaisuriya P, et al. Thalassemia and Hemoglobinopathies in an Ethnic Minority Group in Northern Vietnam. Hemoglobin. 2019;43(4-5):249-53.

16. Ahmad R, Saleem M, Aloysious NS, Yelumalai P, Mohamed N, Hassan S. Distribution of alpha thalassaemia gene variants in diverse ethnic populations in malaysia: data from the institute for medical research. Int J Mol Sci. 2013;14(9):18599614.

17. Lithanatudom P, Khampan P, Smith DR, Svasti S, Fucharoen S, Kangwanpong D, et al. The prevalence of alpha-thalassemia amongst Tai and Mon-Khmer ethnic groups residing in northern Thailand: A population-based study. Hematology. 2016;21(8):480-5.

18. Nguyen NT, Sanchaisuriya K, Sanchaisuriya P, Van Nguyen H, Phan HTT, Fucharoen G, et al. Thalassemia and hemoglobinopathies in an ethnic minority group in Central Vietnam: implications to health burden and relationship between two ethnic minority groups. J Community Genet. 2017;8(3):221-8.

19. Kulaphisit M, Kampuansai J, Leecharoenkiat K, Wathikthinnakon M, Kangwanpong D, Munkongdee T, et al. A comprehensive ethnic-based analysis of alpha thalassaemia allelle frequency in northern Thailand. Sci Rep. 2017;7(1):4690.

20. GoB. The Chittagong Hill Tracts Peace Accord of 1997. In.: National Committee on Chittagong Hill Tracts Affairs, Government of Bangladesh Available at 
https://www.ilo.org/dyn/natlex/docs/ELECTRONIC/87975/100450/F1549787842/BGD87975.pdf.

21. CU. Chittagong University Undergraduate Admission Instruction 2018-2019. In.; 2018.

22. Charan J, Biswas T. How to calculate sample size for different study designs in medical research? Indian J Psychol Med. 2013;35(2):121-6.

23. Sadiya S, Khan WA, Banu B, Sarwardi G, Rahman Y. Carrier Detection of Thalassaemia and Haemoglobinopathies in Tribal Population of Bangladesh. Bangladesh Med Res Counc Bull. 2018;44(2):89-92.

24. Causes and Consequences of Consanguinity in Bangladesh and Pakistan Accessed on May 5. 2019 https://faculty.som.yale.edu/mushfiqmobarak/causes-and-consequences-of-consanguinity-in-bangladesh-and-pakistan/.

25. Internet Subscribers in Bangladesh January. 2018 http://www.btrc.gov.bd/content/internet-subscribers-bangladeshjanuary-2018.

26. Social Media Stats Bangladesh. https://gs.statcounter.com/social-media-stats/all/bangladesh.

\section{Figures}

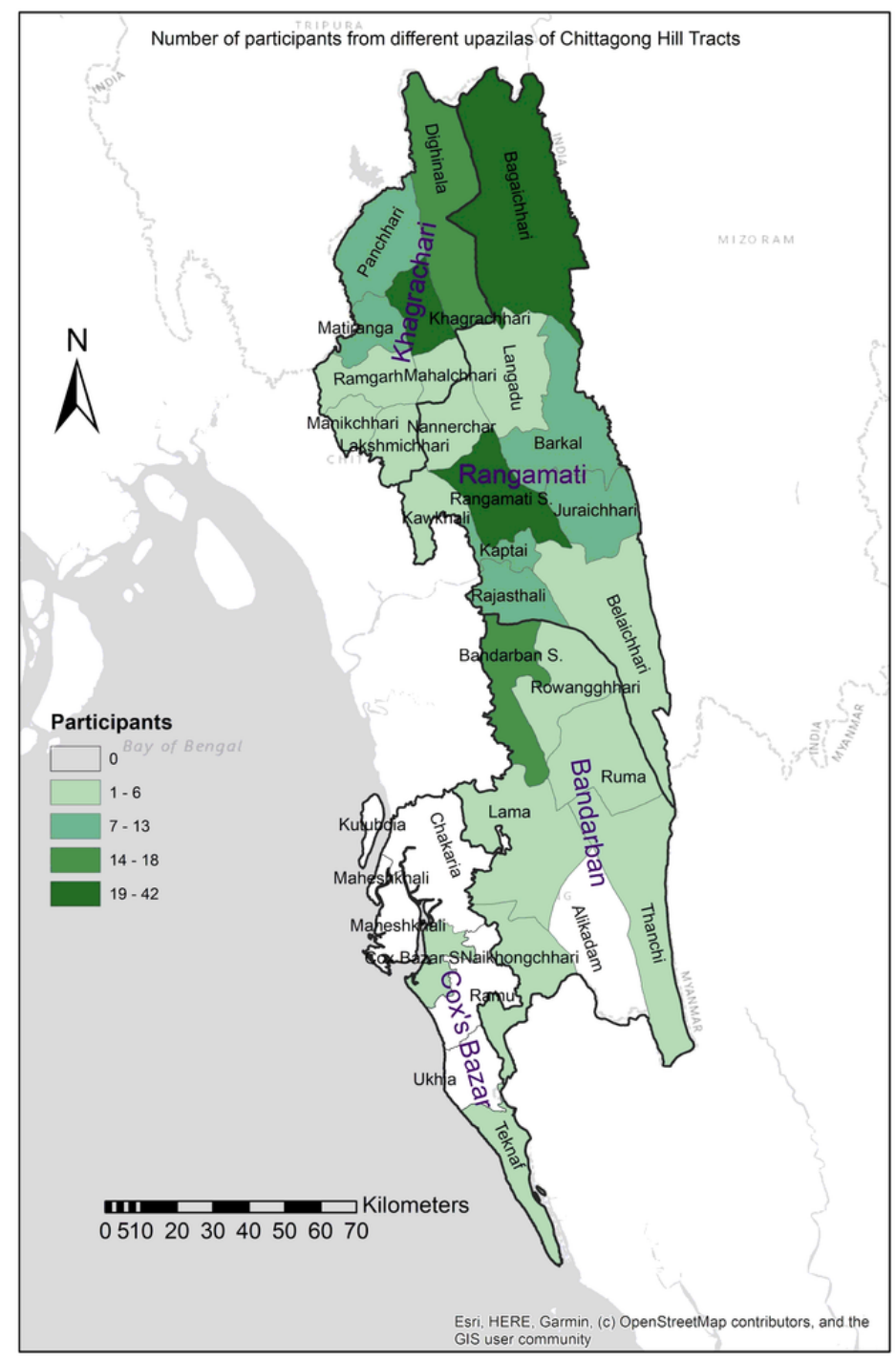


Figure 1

Spatial distribution of the tribal students participated in the survey of this study $(\mathrm{N}=251)$.

\section{Supplementary Files}

This is a list of supplementary files associated with this preprint. Click to download.

- Additionalfiles.docx 